\title{
FINDING OF NO SIGNIFICANT IMPACT; ATLANTIC RICHFIELD COMPANY AND INTALCO ALUMINUM CORPORATION
}

AGENCY: Department of Energy, Fossil Energy

ACTION: Finding of No Significant Impact (FONSI)

SUMMARY: On February 27, 1989, the Department of Energy (DOE) issued Opinion and Order No. 301 (Order 301 ) to Atlantic Richfield Company (ARCO) conditionally authorizing the importation of Canadian natural gas for use in its refinery near Ferndale, Washington. On February 28, 1989, the DOE i"ssued Opinion and Order No. 302 (Order 302 ) to Intalco Alumirum Corporation (Intalco) conditionally authorizing the importation of Canadian natural gas for use in its aluminum smelting plant near Ferndale, washington. ARCO was authorized to import up to 25 billion cubic feet (BCf) and Intalco 2 Bcf per year of natural gas over a two-year period beginning on the date when the Ferndale Pipeline System commences service. However, both conditional orders provided that the issues raised in the proceedings would be reexamined upon subsequent completion of National Environmental Policy Act (NEPA) requirements for the Ferndale Pipeline project and that the final action would then be taken on the conditional orders. Also, pending final action, upon request by $A R C O$ and Intalco, both orders were amended to allow additonal quantities of natural gas to be imported using the existing facilities. On September 22, 1989, Opinion and order No. 301-A (Order 301-A) amended Order 301 to permit ARCO to import using existing facilities. On November 14, 1989, Opinion 
and Order No. 302-A (Order 302-A) amended Order 302 to permit Intalco to import using existing facilities.

The Federal Energy Regulatory Commission (FERC), in connection with an application by ARCO and Intalco to construct and operate the Ferndale Pipeline system natural gas import point, prepared an Environmental Assessment (EA) on the proposed pipeline in consultation with the Washington Department of Fisheries, the U.S. Fish and Wildlife Service, the Washington State Department of Community Development, Office of Archeology and Historic Preservation (Department of Community Development), and the Whatcom County Bureau of Buildings and Code Administration. On December 7, 1989, the FERC, in an order issuing the certificate to ARCO and Intalco, FERC Docket No. CP89-267-000, determined that the Ferndale Pipeline System project would not constitute a major Federal action significantly affecting the quality of the human environment provided that the facilities that were proposed to be constructed by ARCO WEstern Pipeline Compary (ARCO Western) to transport Canadian natural gas for ARCO's refinery and Intalco's aluminum smelting plant were constructed in accordance with the FERC's order directing that certain mitigating steps be taken to protect the quality of the environment.

These steps included adopting construction procedures, mitigative measures, and route alignments as described by ARCO and Intalco in their application as supplemented. Further, the 
FERC order stated that construction on the pipeline that was proposed could not commence until the Director of the FERC Office of Pipeline and Producer Regulation gave written authorization that the revised "Cultural Resource Evaluations and Monitoring Plan for the Proposed Ferndale Pipeline" could be implemented and that construction could proceed. On April 12, 1990, the Director of the office of Pipeline and Producer Regulation informed ARCO and Intalco that, based on information filed by the Department of Community Development, it had been determined that the implementation of the revised cultural resources and monitoring plan should insure that the proposed construction activities would not affect cultural resources and that construction could proceed.

The proposals by $A R C O$ and Intalco involve the transportation of Canadian gas over new facilities, known as the Ferndale Pipeline system, recently constructed by ARCO Western, which acted as agent for $A R C O$ and Intalco. The project includes the construction and operation of a natural gas import point, located at the Canadian border near the town of sumas, washington and a connecting 28.7-mile, 16-inch-diameter mainline pipeline from the United States/Canadian border interconnection with westcoast Energy Inc. (Westcoast) to the ARCO refinery and a $3.7-m i l e$, 8 5/8-inch-diameter lateral pipeline to the Iritalco smelter near Ferndale, Washington.

Thie DOE has reviewed the Ferndale Pipeline System project EA 
prepared by the FERC which addresses the construction of these new facilities and is adopting this EA as DOE/EA-0460. Based on the EA and an independent evaluation, DOE has determined that the environmental conditions imposed by order 301 and 302 have been satisfied and that operation of the Ferndale Pipeline system project would not constitute a major Federal action significantly affecting the quality of the human environment within the meaning of NEPA, since ARCO Western has constructed the facilities in accordance with the mitigating provisions imposed by the FERC December 7,1989 , order to protect the quality of the environment. Neither an envixonmental impact statement (EIS) nor an additional EA is therefore required.

\section{PUBLIC AVAILABILITY:}

The EA prepared by the FERC and adopted by the DOE are publicly available. Anyone wishing to receive a copy of this document, as well as a copy of the DOE FONSI for the Ferndale Pipeline system project should contact:

John W. Glynn

Office of Fuels Programs

Fossil Energy

Department of Energy 1000 Independence Avenue, S.W. Washington, D.C. 20585

(202) 586-9482

For further information on the DOE NEPA process contact:

Carol Borgstrom

Office of NEPA Oversight (EH-25)

Department of Energy

1000 Independence Avenue, S.W.

Washington, D.C. 2.0585

(202) 586-4600 


\section{SUPPLEMENTAL INFORMATION :}

The import or export of natural gas is subject to section 3 of the Natural Gas Act and is under the furisdiction of DOE. order 301 1ssued by DOE on February 27, 1989 (as amended in order 301-A), authorized ARCO to import up to 25 BCf per year of natural gas for two years beginning on the date of first delivery. Order 302 issued by DOE on February 28, 1989 (as amended in Order $302-A$ ), authorized Intalco to import up to 2 Bcf per year of natural gas for two years beginning on the date of first delivery.

According to the proposed operation of the Ferndale pipeline System project, ARCO wor la import Canadian natural gas for use in its Cherry Point Refinery near Ferndale, Washington and Intalco for its aluminum smelting plant near Ferndale, washington. The Fexndale Pipeline system included the construction by ARCO Western of a natural gas import point interconnection with Westcoast at the Canadian border near sumas, washington and a connecting 28.7-mile, 16-inch-diameter mainline pipeline to the ARCO refinery and a 3.7-mile, 8 5/8-inch-diameter lateral pipeline to the Intalco smelter near Ferndale, Washington. With the exception of a 3:700-foot-long section of pipeline located approximately 1.5 miles south of the import point, the entire pipeline facilities are located parallel and adjacent to the existing Cascade Natural Gas Coxporation (Cascade) and Northwest Pipeline Corporation (Northwest) natural gas pipeline 
facilities which currently serve the ARCO refinery and Intalco smelter. Construction of the pipeline facllities required a 75-foot-wide construction right-of-way, of which 30 feet will be maintained as permanent right-of-way. Because the route is located parallel and adjacent to existing rights-of-way for almost its entire length, the FERC delermined that the use of alterrative routes which deviated from existing rights-of-way was not preferable to the route that was proposed.

The FERC determined that if the facilities were constructed in accordance with ARCO's and Intalco's application and supplements filed with the FERC, as well as the recommendations of the FERC EA, approval of the site of importation would not constitute a major Federal action significantly affecting the quality of the human environment and would not require the preparation of an EIS.

DOE has reviewed the FERC EA and is adopting it as DOE/EA-0460 in partial satisfaction of its NEPA responsibilities regarding the conditions imposed in Orders $301,301-A, 302$, and $302 \cdots A$.

\section{DETERMINATION:}

Based on the adopted EA and the DOE's independent evaluation of the environmental effects of the construction and operation of the Ferndale Pipeline system project, the DOE has determined that the project does not constitute a major Federal action signiflcantly affecting the quality of the human environment 
within the meaning of NEPA. Therefore, neither an EIS nor an additional EA is required.

Issued in Washington, D.C., on 1990.

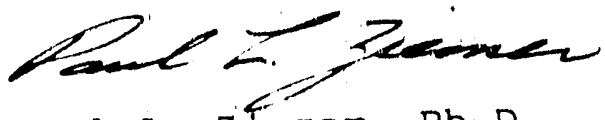

Paul L. Ziemer, Ph.D.

Assistant Secretary

Environment, Safety and Health 


\section{FONSI for Atlantic Richfield company and Intalico Aluminum corporation}

Docket No. CP89-267-000

The Environmental Compliance and Project Analysis Branch requests that the accomfanying environmental assessment be uppended to the OPPR memorandum to the commission and that the following finding of no significant impact be included in the Commission order:

The OPPR staff prepared an environmental assessment (EA) for Arco's and Intalco's proposal to construct and operate an import point, $28.7 \mathrm{mlles}$ of 16-inch-diameter pipeline, and 3.7 miles of 8 5/8-inch-diameter pipeline, all of which would be located in Whatcom County, Washington. The EA addressed construction of the import point and pipeline facilities, land use, revegetation of disturbed areas, erosion control, federally listed threatened and endangered species, cultural resources, stream-crossing methods, wetland construction techniques, and alternatives to the proposed action.

With the exception of a 3,700-foot-long section of pipeline located approximately 1.5 miles south of the import point, the entire proposed pipeline facilities would be located parallel and adjacent to the existing Cascade Natural Gas Corporation (Cascade) and Northwest Pipeline Corporation (Northwest) natural gas pipeline facilities which currently serve the applicants' manufacturing plants.

No recreational areas, such as parks, wildilfe refuges, or forests would be crossed. No permanent residences are located within 50 feet of the proposed facilities. Revegetation of areas disturbed by the construction of the proposed facilities would be performed by Arco Western.

The proposed facilities would cross a total of 15 perennial streams, all of which provide spawning and/or rearing habitat for trout and salmon populations, as well as two wetland areas for is distance of 0.2 mile. Arco and Intalco have consulted extensively with the washington Department of Fisheries (WDF) regarding potential adverse impact on fishery and wetland resources, and have agreed to utilize special construction techniques to mitigate impact on these resources.

The staff has determined, through informal consultation with the U.S. Fish and Wildlife Service (FWS), that an active bald eagle nest (a federaliy listed threatened species in the state of Washington) is located approximately 0.25 mile south of the proposed terminus of the lateral 
pipeline on property owned by Intaloo. Staff's review of aerial photographs of the area revealed that the nest is shielded from direct view of the proposed project by an existing railxoad right-of-way and numerous large-diameter trees. In addition, the resident bald eagles are acclimated to and tolerate noise emanating from industrial operations within Intalco's manufacturing facilities. Based on this information, as well as consultations with the FWs, the staff concludes that construction of the proposed facilities would not adversely affect the bald eagles nesting in this location. No state-listed species would be affected.

The staff, in consultation with the washington state Historic Preservation officer (SHPO), has determined that the proposed project would not affect any known cultural resources on or eligible for inclusion on the National Register of Historic Places. However, the staff has determined that there is a high potential for deeply buried cultural resources to be discovered during construction, and that cultural resource monitoring during pipeline construction is necessary to identify and evaluate the significance of any cultural resources inadvertently discovered during construction. The staff has reviewed Arco's and Intalco's proposed construction monitoring plan, and determined that it is adequate to identify and evaluate the significance of cultural resources inadvertently discovered during construction. The washington state Historic Preservation officer (SHPO) has concurred with the stafi's conclusion.

However, the Advisory Council on Historic Preservation (Advisory Council), in its comments on the monitoring plan, provided the staff with several extensive recommendations that the Advisory Council requested be implemented in order to ensure that the proposed project would not have an adverse affect on historic properties. The commission staff is currently evaluating the Advisory Council's recommendations, and will coordinate its revisions to the proposed cultural resource monitoring plan with the applicants, washington SHPO, and Advisory Council, as appropriate.

Therefore, the staff recommends that Arco and Intalco not commence construction of the proposed pipeline facilities until the Director, Offlce of pipeline and Producer Regulation, has given written authorization that the revised "Cultural Resource Evaluations and Monitoring plan for the Proposed Ferndale Pipelinen can be implemented and that constructicn may proceed. 
Because the proposed route is located parallel and adfacent to existing rights-of-way for almost its entire length, the staff determined that the use of alternative routes which deviated from existing rights-of-way were not preferable to the proposed route.

The staff also analyzed the No Action Alternative. Under the No Action Alternative, the proposed project would not receive certification and Arco and Intalco would continue to receive supplies of natural gas purchased on the Canadian spot market and transported via Northwest's and Cascade's existing pipeline facilities.

In order to constitute a viable alternative under the No Action scenario, Cascade's and Northwest's systems must be capable of providing an equivalent type and level of service as that proposed by the applicants: that is, firm transportation services to Arco and Intalco for a total maximum of 105 MMcf of natural gas per day, which is the design capacity of the applicants' proposed pipeline facilities. Both Cascade and Northwest have stated that their individual systems are capable of providing the type (i.e., firm) and level (1.e., 105 Mycf of natural gas per day) of service that is requested by $A$ rco and Intalco. The staff notes that Arco and Intalco have not disputed this statement, and believes that the existing pipeline systems can provide the requested type and level of service.

Based on the staff's review of Arco's and Intalco's application and the supplements filed with the Commission, the Environmental Compliance and Project Analysis Branch (ECB) has determined that the environmentally preferred alternative in this docket is the No Action Alternative-that is, that Arco and Intalco should continue to receive natural gas supplies through Cascade's and Northwest's existing natural gas pipeline facilities, and that the applicants should not be authorized to construct and operate duplicative pipeline facilities.

Use of the existing pipeline facilities would eliminate the short-term impact associated with constructing 32.4 miles of pipeline, as well as the long-term impact associated with creating and maintaining 118 acres of permanent right-of-way. In addition, use of the existing facilities would obviate the need to construct across 15 perennial streams that provide spawing and/or rearing habitat for trout and salmon populations, as well as eliminate the possibility that previously unknown cultural resources would be discovered and potentially affected during construction. 
However, the ECB recognizes that environmental impact is only one of the factors that the commission considers in its deliberations, and that other factors of public convenience and necessity may outweigh potential environmental impact and thereby justify construction of the proposed pipeline facilities. In the event that the Commission authorizes the construction of the proposed facilities, the ECB has determined that if the proposed facilities are constructed in accordance with Arco's and Intalco's application and supplements filed wiih the commission, as well as the stafe's recommendation below, Commission approval of this proposal would not constitute a major Federal action significantly affecting the quality of the human environment.

As recommended in the staff's EA, the following conditions are hereby placed in the authorization granted herein:

1. Arco and Intalco shall not commence construction of the proposed pipeline facilities until the Director, office of Pipeline and Producer Regulation, has given written authorization that the revised "Cultural Resource Evaluations and Monitoring Plan for the Proposed Ferndale Pipeline" can be implemented and that construction may proceed.

2. Arco and Intalco shall adopt the construction procedures, mitigative measures, and route alignment described in their application and supplements filed with the Commission on January 5, 1989, March 3, 1989, April 21, 1989, May 24, 1989, June 29, 1989, and July 10, 1989, and as further discussed in the EA. 
ATTACHMENT

Atlantic Richfield Company and Intalco Aluminum Corporation Docket No. CP89-267-000

\section{ENVIRONMENTAL ASSESSMENT}

\section{Proposed Action}

The Atlantic Richfield Company (Arco) and Intalco Aluminum Corporation (Intalco) seek a Presidential Permit authorizing the construction and operation of a natural gas import point, located at the Canadian border near the town of Sumas, Washington. Arco and Intalco also seek authority to construct, operate, maintain, and connect approximately 28.7 miles of 16 -inch-diameter mainline pipeline from the import point to the vicinity of the Arco!s Cherry point Refinery located near the town of Ferndale, Washington, and 3.7 miles of $85 / 8$-inch-diameter lateral pipeline from Arco's Cherry Point Refinery to Intalco's Aluminum

Corporation Plant. All of the proposed facilities are located in Whatcom County, Washington.

The proposed facilities would be constructed and operated by the Arco Western Pipeline Company (Arco Western), who would act as agents for Arco and Intalco. These facilities would be used to transport approximately 105 MMcf of natural gas per day for the sole use of the applicants at their manufacturing facilities, and would cost approximately $\$ 11,000,000$.

The applicants currently receive natural gas supplies, purchased on the spot market in Canada by Cascade Natural Gas Corporation (Cascade) on the applicants' behalf, via existing natural gas pipeline facilities owned by Cascade and Northwest Pipeline Corporation (Northwest). The applicants state that the iransportation charges of Cascade and Northwest exceed the value of the services these companies provide, and that construction of the proposed facilities is justified on the grounds that it would provide more reliable service at a lower cost.

with the exception of a 3,700-foot-long section of pipeline located approximately 1.5 miles south of the import point, the entire proposed pipeline facilities would be located parallel and adjacent to the existing Cascade and Northwest natural gas pipeline facilities which currently serve the applicants' manufacturing plants. Construction of the proposed pipeline facilities would require the use of a 75-foot-wide construction right-of-way, of which 30 feet would be maintained as permanent right-of-way. 


\section{Environmental Analysis}

The area in which the proposed facilities would be constructed is relatively flat, with limited local relief provided by hills of glacial moraine origin. Land use in the provided by hilis of glacial moraine origln.
area is primarily agricultural or pastureland ( 81 percent), with
primary crops consisting of forage production for dairy livestock. Other land uses affected by forests ( 18 percent) and include isolated woodlots and ripariated with Arco's and Intalco's industrial lands

There are no major geological features, unstable sediments, or other hazards present in the propos ad project area. No recreational areas, such as parks, wildlife refuges, or forests would be crossed. No permanent residences are located within 50 feet of the proposed facilities.

Revegetation of areas disturbed by the construction of the proposed facilities would be performed by Arco Western and would incluce: the application of fertilizer and/or manure; reseeding with a temporary cover crop consisting of perennial if is spring wheat, spring rye, and barley, ipplication of straw mulch. completied in the late lalli and occur in the following spring Permanent revegetation would completion of construction) and would utilize (assuming late-fall completicies, depending on land use and soil a variety of vegetations. The staff has reviewed the proposed revegetation mixtures and application raturbed right-of-way.

Topsoil located over the trench on agricultural lands would be segregated during construction, and would be restored to its original horizon during restoration of the disturbed right-ofway. No agricultural drainage tile would be disturbed by construction of the proposed facilities. The staff has reviewed Arco Western's proposed Erosion and Sediment Control Plan (Plan), and concludes that implementation of the Plan would prevent the occurrence of significant erosion-related impact.

The proposed facilities would cross a total of 15 perennial treams, all of which provide spawning and/or rearing habitat for trout and salmon populations. Arco, Intalco and the staff have consulted extensively with the washington Department of Fisheries (WDF) regarding potential adverse impact on fishery resources. At the request of the WDF, Arco and Intalco have agreed to directionally drill three of the proposed stream crossings (Sumas River, Fishtrap Creek, and Bertrand Creek), and would construct the other crossings between July 1 and October 1 utilizing the flume-pipe method. In the event that these remaining streams must be crossed outside this time-period, Arco Western has agreed to directionally drill the crossings in order to avoid adverse 
impacts on spawning salmon and trout populations. In addition, Arco Western has agreed, in coordination with the WDF, to enhance fish jabitat in these streams through the use of in-stream placement of gravel and replanting of shrubs on the disturbed streambariks. The staff has determined that implementation of Arco Western's proposed stream crossing techniques would prevent the occurrence of significant impact on fishery and water resources.

The proposed facilities would cross two palustrine scrubshrub wetlands for a total distance of 0.2 mile. Arco Western would minimize grading and disturbance to these areas, and would utilize timber mats and/or the push-pull method of pipeline installation as necessary. All temporary fill materials would be removed, and the disturbed areas would be promptly revegetated. Also, at the request of the WDF, ArCo and Intalco have agreed to install temporary fencing around one of these wetlands in order to exclude grazing livestock and allow for prompt revegetation of all disturbed areas. Implementation of these techniques would prevent the occurrence of significant impact on wetland resources.

The staff has determined, through informal consultation with the U.S. Fish and Wildlife service (FWS), that an active bald eagle nest (a federally listed threatened species in the state of Washington) is located approximately 0.25 mile south of the proposed terminus of the lateral pipeline on property owned by Intalco. Staff's review of aerial photographs of the area revealed that the nest is shielded from direct view of the proposed project by an existing railroad right-of-way and numerous large-diameter trees. In addition, the resident bald eagles are acclimated to and tolerate noise emanating from industrial operations within Intalco's manufacturing facilities. Based on this information, as well as consultations with the FWS, the staff concludes that construction of the proposed facilities would not adversely affect the bald eagles nesting in this location. No state-listed species would be affected.

The staff, in a data request dated February B, 1989, requested that Arco and Intalco (as a non-Federal party) undertake certain efforts to assist the Commission in evaluacing the proposed project's effect on cultural resources on or eligible for inclusion on the National Register of Historic Places (Register), as required under section 106 of the National Historic Preservation Act (NHPA) (36 CFR 800). In a letter filed with the Commission on March 3, 1989, Arco and Intalco indicated that they would conduct an intensive cultural resources survey of the proposed facilities, which would include the use of pedestrian surveys, consultation with regional experts and Indian tribal representatives, extensive surface observation, and subsurface discovery strategies. In addition, the survey proposal indicated that because some deeply buried sites may 
remain undiscovered until construction, specific construction monitoring procedures would be developed to identify and evaluate potential eligibility for inclusion on the Register.

Arco and Intalco filed the results of their intensive cultural resource survey with the Commission on May 24, 1989. The survey report indicated that two prehistoric and two historic sites were located along the proposed pipeline route, and that minor route deviations had been made to avoid impact, on these sites. However, the report also indicated that while the entire pipeline route was walked by qualified archaeologists, over 50 percent of the route was covered with dense vegetation which precluded observation of the soil surface. In addition, the report acknowledged that, due to the presence of deeply alluviated soils in the project area, no subsurface sampling was conducted. Finally, the report concluded that much of the route possessed a high cultural resource sensitivity, and recommended construction monitoring to record any cultural resources found during grading and trenching operations.

The staff reviewed the survey report and concluded that the sampling procedures utilized, as well as the monitoring procedures proposed, would not allow the commission to fulfill its obligations under section 106 of the NHPA. The staff subsequently held numerous discussions with Arco's and Intalco's environmental consultants (ENSR) concerning the need to conduct additional subsurface cultural resource surveys. In addition, recognizing the high probability that deeply buried cultural resources could inadvertently be discovered during construction, the staff informed ENSR that a detailed, operationalized monitoring plan (which would be implemented during construction) needed to be developed and submitted to the staff for its approval.

Arco and Intalco filed the results of the requested subsurface survey and the proposed monitoring plan with the Commission on July 10, 1989. The staff has reviewed the survey results, in consultation with the washington state Historic Preservation officer (SHPO), and determined that the proposed project would not affect any known cultural resources on or eligible for inclusion on the Register. In addition, the staff has determined that Arco's and Intalco's proposed monitoring plan is adequate to identify and evaluate the significance of additional cultural resources inadvertently discovered during construction. In letter dated August 2, 1989, the washington SHPO informed the commission staff that it concurred with the proposed monitoring plan.

In a letter dated October 20, 1989, the Advisory Council on Historic Preservation (Advisory Council) informed the Commission staff, pursuant to the NHPA implementing regulations at $36 \mathrm{CFR}$ 800.5 and 36 CFR 800.11 , that it igreed in principle with the 
implementation of Arco's and Intalco's proposed cultural resource monitoring plan. However, the Advisory council provided the Commission staff with several extensive recommendations that the Advisory Council requested be implemented in order to ensure that the proposed project would not have an adverse affect on historic properties. These recommendations concerned: appropriate methodologies for the collection, analysis, and recovery of cultural resource materials; coordination between Federal, state, and county agencies, and Indian tribes, and; treatment of burial sites and Indian remains.

The Commission staff is currently evaluating the Advisory council's recommendations, and will coordinate its revisions to the proposed cultural resource monitoring plan with the applicants, washington SHPO, and Advisory Council, as appropriate. Therefore, the staff will recommend that Arco and Intalco not commence construction of the proposed pipeline facilities until the cultural resource monitoring plan has been revised according to the staff's recommendations, and the Director, office of Pipeline and producer Regulation has given written authorization that the revised cultural resource monitoring plan can be implemented and that construction may proceed.

Under the Washington state Environmental Policy Act, primary environmental review of proposed construction projects is delegated to the affected county government(s). The proposed project is located entirely within whatcom county, and the designated environmental review agency is the Whatcom county Bureau of Buildings and Code Administration (Administration). January 5, 1989, the Administration issued a "Mitigated Determination of Nonsignificance", which concluded that the proposed project would not result in significant adverse impact on the environment, and that a state-issued environmental impact statement was not required.

\section{Alternatives}

Because the proposed route is located parallel and adjacent to existing rights-of-way for almost its entire length, the staff determined that the use of alternative routes which deviated from existing rights-of-way were not preferable to the proposed route.

The staff also analyzed the No Action Alternative. Under the No Action Alternative, the proposed project would not receive certification and Arco and Intalco would continue to receive supplies of natural gas purchased on the Canadian spot market and transported via Northwest's and Cascade's existing pipeline facilities. The No Action Alternative would eliminate the shortterm impact associated with constructing 32.4 miles of pipeline, 
as well as the long-term impact associated with creating and maintaining 118 acres of permanent pipeline right-of-way.

In order to constitute a viable alternative under the No Action scenario, Cascade's and Northwest's systems must be capabie of providing an equivalent type and level of service as that proposed by the applicants: that is, firm transportation services to Arco and Intalco for a total maximum of 105 MMcf of natural gas per day, which is the design capacity of the applicants' proposed pipeline facilities. Both Cascade and Northwest have stated that their individual systems are capable of providing the type (i.e., firm) and level (i.e., 105 MMCf of natural gas per day) of service that is requested by Arco and Intalco. The staff notes that Arco and Intalco have not disputed this statement, and believes that the existing pipeline systems can provide the requested type and level of service. Since Cascade and Northwest can provide a type and level of service equivalent to the applicants' proposal by using their existing systems, the staff concludes that the No Action Alternative is the environmentally preferred alternative.

The applicants' sole justification for constructing the proposed facilities is that the transportation charges of cascade and Northwest exceed the value of the services they provide, and that the proposed facilities would provide more reliable service at a lower cost. However, Cascade has stated that its new Rate Schedule 565, which was approved by the washington utility Transportation Commission and became effective June 1, 1989, offers considerable savings to Arco and Intalco over Cascade's present rates, and would result in costs to Arco and Intalco that are equal or less than those that would be incurred by constructing and operating the proposed facilities. As a result, the underlying premise on which the need for the proposed project is founded is in dispute. However, the staff notes that its environmental assessment is not the proper forum for determining whether or not Cascade's new Rate schedule 565 would result in costs to Arco and Intalco that are equal or less than those which would be incurred by constructing and operating the proposed facilities.

\section{Conclusions and Recommendations}

Based on the staff's review of Arco's and Intalco's application and the supplements filed with the commission, the Environmental Compliance and Project Analysis Branch (ECB) has determined that the environmentally preferred alternative in this docket is the No Action Alternative. That is, Arco and Intalco should continue to receive natural gas supplies through Cascade's and Northwest's existing pipeline facilities, and that the applicants should not be authorized to construct and operate duplicative pipeline facilities. 
Use of the existing pipeline racilities would eliminate the short-term impact associated with constructing 32.4 miles of pipeline, as well as the long-term impact associated with creating and maintaining 118 acres of permanent right-of-way. In addition, use of the existing facilities would obviate the need to construct across 15 perennial streams that provide spawning and/or rearling habitat for trout and salmon populations, as well as eliminate the possibility that previously unknown cultural resources would be discovered and potentialiy affected during construction.

However, the ECB recognizes that environmental impact is only one of the factors that the commission considers in its deliberations, and that other factors of public convenience and necessity may outweigh potential environmental impact and thereby justify construction of the proposed pipeline facilities. In the event that the commission authorizes the construction of the proposed facilities, the ECB has determined that if the proposed facilities are constructed in accordance with Arco's and Intalco's application and supplements filed with the commission, as well as the staff's recommendations below, commission approval of this proposal would not constitute a major Federal action significantly affecting the quality of the human environment. The staff recommends including a finding of no significant impact (FONSI) in the Commission order. See the attached FONSI.

Furthermore, if the commission approves the proposed project, it is recommended that the following conditions be included in the order issuing a certificate to mitigate the environmental impact:

1. Arco and Intalco shall not commence construction of the proposed pipeline facilities until the Director, office of Pipeline and Producer Regulation, has given written authorization that the revised "Cultural Resource Evaluations and Monitoring Plan for the Proposed Ferndale Pipeline" can be implemented and that construction may proceed.

2. Arco and Intalco shall adopt the construction procedures, mitigative measures, and route alignment described in their application and supplements filed with the Commission on January 5, 1989, March 3, 1989, April 21, 1989, May 24, 1989 , June 29, 1989, and July 10,1989 , and as further discussed in the EA. 

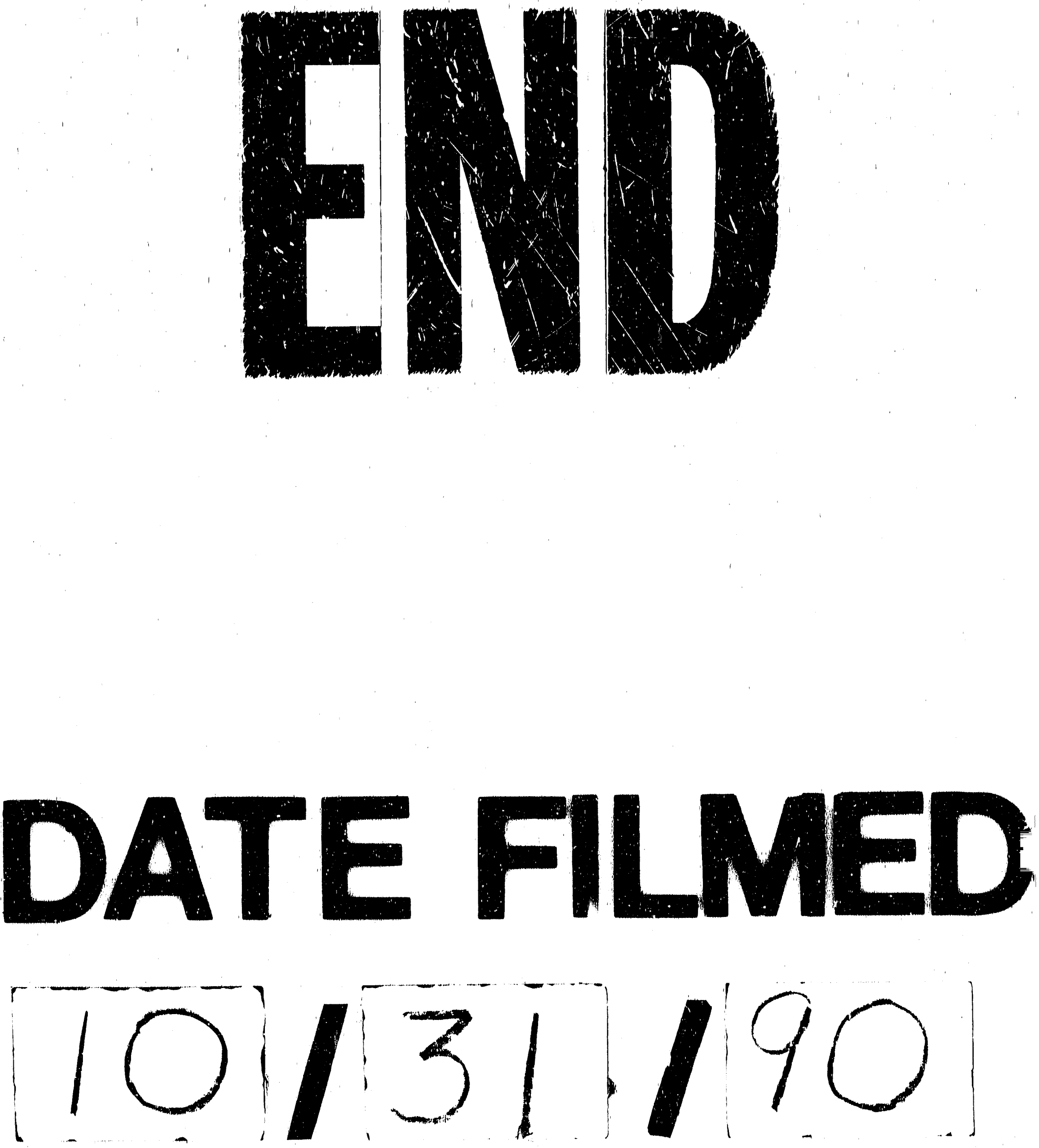
